\title{
ORIGINAL ARTICLE \\ Is there more than one way to skin a newt? Convergent toxin resistance in snakes is not due to a common genetic mechanism
}

\author{
CR Feldman ${ }^{1}$, AM Durso ${ }^{2}$, CT Hanifin ${ }^{2,3}$, ME Pfrender ${ }^{4}$, PK Ducey ${ }^{5}$, AN Stokes $^{6}$, KE Barnett $^{7}$, ED Brodie III ${ }^{8}$ \\ and ED Brodie $\mathrm{Jr}^{2}$
}

Convergent evolution of tetrodotoxin (TTX) resistance, at both the phenotypic and genetic levels, characterizes coevolutionary arms races between amphibians and their snake predators around the world, and reveals remarkable predictability in the process of adaptation. Here we examine the repeatability of the evolution of TTX resistance in an undescribed predator-prey relationship between TTX-bearing Eastern Newts (Notophthalmus viridescens) and Eastern Hog-nosed Snakes (Heterodon platirhinos). We found that that local newts contain levels of TTX dangerous enough to dissuade most predators, and that Eastern Hog-nosed Snakes within newt range are highly resistant to TTX. In fact, these populations of Eastern Hog-nosed Snakes are so resistant to TTX that the potential for current reciprocal selection might be limited. Unlike all other cases of TTX resistance in vertebrates, H. platirhinos lacks the adaptive amino acid substitutions in the skeletal muscle sodium channel that reduce TTX binding, suggesting that physiological resistance in Eastern Hog-nosed Snakes is conferred by an alternate genetic mechanism. Thus, phenotypic convergence in this case is not due to parallel molecular evolution, indicating that there may be more than one way for this adaptation to arise, even among closely related species.

Heredity (2016) 116, 84-91; doi:10.1038/hdy.2015.73; published online 16 September 2015

\section{INTRODUCTION}

The repeated evolution of similar phenotypes in response to similar selective pressures, or convergent evolution, is a pervasive evolutionary phenomenon (Schluter, 2000; McGhee, 2011; Futuyma, 2013). Major questions remain regarding the ecological and evolutionary causes of convergence, including whether convergent evolution most often results from selection toward optimality, or from constraints on design, genetic architecture or other contingencies (Maynard Smith et al., 1985; Wake, 1991; Brakefield, 2006; Christin et al., 2010; Losos, 2011). Examining the genetic basis of convergence provides insight into these questions, because we can assume selection is relatively unconstrained when similar phenotypes are produced through diverse genetic routes and, conversely, that constraints may be important when phenotypes are determined by a limited subset of possible genetic mechanisms (Miller et al., 2006; Weinreich et al., 2006; Gompel and Prud'homme, 2009; Losos, 2011; Conte et al., 2012; Feldman et al., 2012). Exploration of these questions requires independent systems with similar, well-defined selection pressures. Chemically mediated interactions among species may provide especially productive systems for examining convergence, because these interactions frequently revolve around compounds with very specific biological effects (Brodie and Ridenhour, 2003).
Animals frequently employ chemical defenses to protect themselves against predation. One of the most potent chemical weapons ever discovered is tetrodotoxin (TTX), a lethal poison found across diverse animal phyla (Hanifin, 2010; Moczydlowski, 2013). TTX is highly effective because of its extremely specific mode of action. It binds selectively to the outer pore of voltage-gated sodium channels $\left(\mathrm{Na}_{\mathrm{v}}\right.$ proteins) in nerves and muscles, blocking the movement of sodium ions $\left(\mathrm{Na}^{+}\right)$across the cell membrane and halting the initiation and propagation of action potentials (Hille, 2001; Fozzard and Lipkind, 2010). By arresting nerve impulses in muscle and nervous tissue, TTX causes immobilization, respiratory failure and often death (Brodie, 1968a; Hanifin, 2010; Moczydlowski, 2013).

Although TTX is found in a diverse array of taxa (Hanifin, 2010; Moczydlowski, 2013), only a few vertebrate groups appear to have evolved the ability to tolerate TTX, including tetraodontid fishes, newts, some frogs and a handful of snakes (for example, Soong and Venkatesh, 2006; Feldman et al., 2012; Hanifin and Gilly, 2015). Of these taxa, snakes are among the only vertebrates known to regularly consume TTX-defended prey (Feldman et al., 2012). Given the highly specific action of TTX, one mechanism of TTX resistance seems obvious: functional changes to the outer pore of sodium channels that reduce the affinity of TTX to the protein. Indeed, all TTX-resistant

${ }^{1}$ Department of Biology, University of Nevada Reno, Reno, NV, USA; ${ }^{2}$ Department of Biology, Utah State University, Logan, UT, USA; ${ }^{3}$ Department of Biology, Utah State University, Uintah Basin, Vernal, UT, USA; ${ }^{4}$ Department of Biological Sciences, University of Notre Dame, Notre Dame, IN, USA; ${ }^{5}$ Department of Biological Sciences, State University of New York-Cortland, Cortland, NY, USA; ${ }^{6}$ Department of Biology, California State University Bakersfield, Bakersfield, CA, USA; ${ }^{7}$ New York State Department of Environmental Conservation, Albany, NY, USA and ${ }^{8}$ Mountain Lake Biological Station and Department of Biology, University of Virginia, Charlottesville, VA, USA

Correspondence: Dr CR Feldman, Department of Biology, University of Nevada Reno, 1664 North Virginia Street, MS 0314, Reno, NV 89557, USA.

E-mail: ophis@unr.edu

Received 7 March 2015; revised 7 June 2015; accepted 8 June 2015; published online 16 September 2015 
vertebrates examined thus far have remarkably similar mutations that alter the structure of the outer pore and reduce TTX-binding affinity to the channel (Geffeny et al., 2005; Soong and Venkatesh, 2006; Jost et al., 2008; Feldman et al., 2012; McGlothlin et al., 2014; Hanifin and Gilly, 2015). In fact, this mechanism of TTX resistance appears nearly identical across several independent, coevolutionary arms races involving predatory snakes and their TTX-defended amphibian prey (Feldman et al., 2009, 2012), as well as across sodium channel paralogs within species (McGlothlin et al., 2014), suggesting that adaptation to TTX is highly predictable (Jost et al., 2008; Feldman et al., 2012; McGlothlin et al., 2014).

We examined a previously undescribed predator-prey relationship to provide an additional test of the predictability of the evolution of TTX resistance at the molecular level, with surprising results. Eastern Hog-nosed Snakes ( $H$. platirhinos) are one of a few vertebrates that regularly consume TTX-defended Eastern Newts (N. viridescens) (summarized in Table 1), even consuming the brightly colored efts (a terrestrial dispersal stage) that are up to 10 times more toxic than adult newts (Brodie, 1968b; Brodie et al., 1974). Here we show that $H$. platirhinos are highly resistant to TTX, where they are sympatric with $N$. viridescens, indicating that these snakes have evolved resistance to their dangerous prey. However, we find no evidence of adaptive changes in the gene controlling TTX resistance in skeletal muscle of all other vertebrates (SCN4A) in Eastern Hog-nosed Snakes. Instead, the evolutionary path to TTX resistance in $H$. platirhinos remains enigmatic. These results highlight the unpredictable nature of genetic evolution, even for traits and ecological challenges typically characterized by a high degree of constraint.

\section{MATERIALS AND METHODS}

Prey phenotype assays

To assess prey phenotypes, we quantified TTX in the skin of $10 \mathrm{~N}$. viridescens efts from New York and 51 from Virginia (Figure 1). We extracted TTX from $1 \mathrm{~cm}^{2}$ skin samples (Hanifin et al., 2002; Lehman, 2007) and measured TTX concentrations using high-performance liquid chromatography (New York samples) (Yasumoto and Michishita, 1985) or competitive inhibition enzymatic immunoassay (Virgania samples) (Lehman, 2007; Stokes et al., 2012), using the linear range of the standard curve between 10 and $500 \mathrm{ng} \mathrm{ml}^{-1}$ to quantify TTX and scoring samples as lacking TTX with values less than the minimum level of detection $\left(10 \mathrm{ng} \mathrm{ml}^{-1} ; n=1\right)$. It is noteworthy that these two methods of quantification (high-performance liquid chromatography and competitive inhibition enzymatic immunoassay) give nearly indistinguishable measures of
TTX concentrations (Lehman, 2007). We then extrapolated measures of TTX in our skin samples to the whole animal using the calculation from Hanifin et al. $(2004,2008)$.

\section{Predator phenotype assays}

To assess predator phenotypes, we assayed TTX resistance in $29 \mathrm{H}$. platirhinos from 9 localities (Table 2 and Figure 1) and 1 Heterodon nasicus (Plains Hognosed Snake), a species that does not consume newts. Our geographic sampling focused mainly on populations in New York, where one of us (KEB) made initial observations of $H$. platirhinos consuming efts in the wild (Barnett et al., 2006). We also included two samples from more disparate locations to make a cursory examination of geographic variation of TTX resistance in $H$. platirhinos: one from northern Virginia (sympatric with newts) and one from eastern Texas (allopatric with newts) (Table 2 and Figure 1).

We measured TTX resistance using a well-established bioassay of wholeanimal performance (Brodie and Brodie, 1990; Ridenhour et al., 2004). Briefly, we placed snakes on a 4-m track lined with infrared sensors to record their sprint speed pre- and postinjection with TTX. After measuring the preinjection baseline speed of each snake, we injected TTX starting at 1 mass-adjusted mouse unit (MAMU) for snakes allopatric with newts (our H. platirhinos from TX and H. nasicus) and 10 MAMUs for snakes sympatric with newts (all other $H$. platirhinos). We then serially increased the doses (5, 10 and 25 MAMUs for snakes allopatric with newts; $25,50,100$ or 250 MAMUs for sympatric snakes) until we could calculate the dose required to reduce sprint speed $50 \%$. It is worth noting that our units of TTX are in MAMUs, where 1 MAMU is the amount of TTX needed to kill a 20 -g mouse in 10 min, adjusted to the mass of each snake. Because of the prohibitive cost of TTX, in a few cases we stopped increasing the dose before a $50 \%$ reduction in speed could be estimated, resulting in a measurement that underestimates true TTX resistance. We omitted snakes that refused to crawl down the racetrack $(n=2)$.

\section{Predator functional genotype assays}

To determine the genetic basis of TTX resistance in snakes, we sequenced the gene (SCN4A) that encodes the skeletal muscle sodium channel $\left(\mathrm{Na}_{\mathrm{v}} 1.4\right)$ from a subset of the hog-nosed snakes we assayed for TTX resistance. These samples included highly resistant sympatric snakes and nonresistant allopatric snakes (six $H$. platirhinos and one $H$. nasicus). The single $\alpha$-subunit of $\mathrm{Na}_{\mathrm{v}} 1.4$ forms a membrane-spanning channel that allows selective permeation of $\mathrm{Na}^{+}$ions (Goldin, 2001; Hille, 2001). The subunit consists of four domains (DI-DIV), each containing four pore forming segments (P-loops) that fold back into the cell membrane to create the outer pore, which is lined with two negatively charged rings of amino acids and terminates in a narrow selectivity filter that preferentially allows $\mathrm{Na}^{+}$ions to pass through the channel (Goldin, 2001; Fozzard and Lipkind, 2010). These same structures that line the outer

Table 1 Records of Eastern Newt (N. viridescens) predation by Eastern Hog-nosed Snakes (H. platirhinos)

\begin{tabular}{llll}
\hline Location of predation by H. platirhinos & Snake age class & Newt stage & Source \\
\hline Washington Parish, LA & Neonate/juvenile & Eft & Williams, 2011 \\
Ozark County, MO & Subadult/adult & Adult & M. Nickerson (personal communication) \\
Wake County, NC & Neonate/juvenile & Eft & Palmer and Braswell, 1995 \\
Wake County, NC & Subadult/adult & Eft & Hurst, 1963 \\
New Hanover County, NC & Neonate/juvenile & Eft & J Hall and R Myers (personal communication) \\
Vinton County, OH & Subadult/adult & Eft & C. Brune and D. Sapienza (personal communication) \\
Saratoga County, NY & Neonate/juvenile & Eft & Barnett et al., 2006; this study \\
Northampton County, PA & Subadult/adult & Eft & McDonald, 1987 \\
Montgomery County, TX & Juvenile/subadult & Eft & This study \\
George Washington National Forest, VA & Unknown & Eft & Uhler et al., 1939 \\
Waukesha County, WI & Neonate/juvenile & Eft & Koch, 2009
\end{tabular}

It is worth noting that most predation events involve neonate or juvenile snakes and all but one record involves efts: the brightly colored sub-adult dispersal stage of Eastern Newts that are up to 10 times more toxic than the adult newts (Brodie, 1968b,Brodie et al., 1974). Records are mapped in Figure 1 and suggest that hognose predation may be widespread and common. Furthermore, feeding trials in captivity suggest that Eastern Hog-nosed Snakes can take multiple efts in a single session. One of us (KEB) has fed up to three efts at a time to captive Eastern Hog-nosed Snakes, where snakes and efts were from the same location in NY; another biologist has fed up to 15 efts to a captive Eastern Hog-nosed Snakes in a single feeding session, where snakes and efts were where snakes and efts were from the same location in NY; another bio
from the same location in OH (D Sapienza, personal communication). 


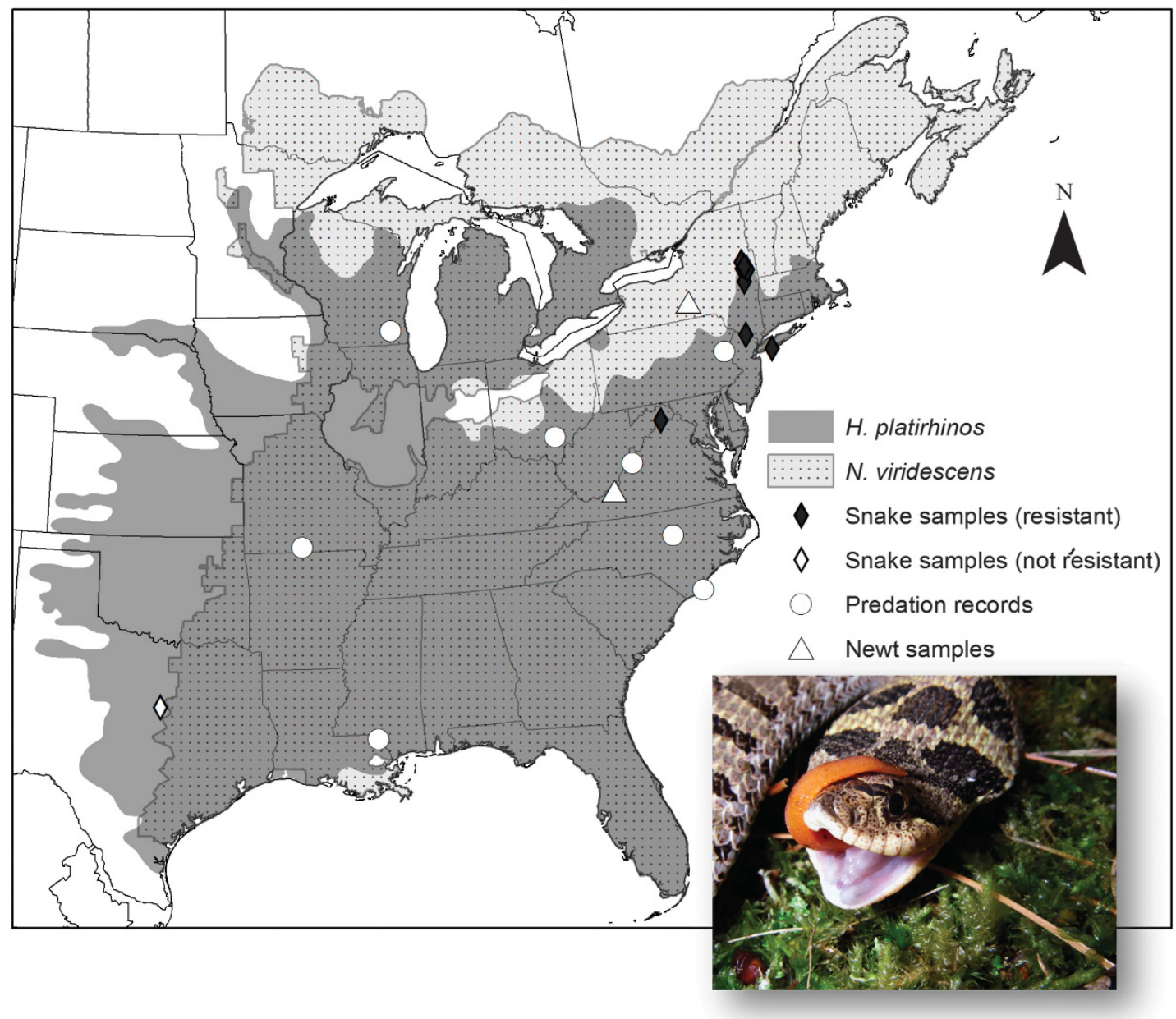

Figure 1 Distribution of Eastern Newts N. viridescens (stippled) and Eastern Hog-nosed Snakes H. platirhinos (gray), showing documented records of newt predation by snakes (circles; Table 1), as well as sample localities of newts (triangles; Figure 2) and snakes (diamonds) used in this study (Table 2). Inset shows an $N$. viridescens eft being ingested (only the tail can be seen) by a H. platirhinos from eastern NY (photo by KEB).

Table 2 Locality information, phenotypes, and sample sizes of hog-nosed snakes (Heterodon)

\begin{tabular}{|c|c|c|c|}
\hline Species locality & TTX resistance (50\% MAMU) & n TTX bioassay & n SCN4A sequence \\
\hline \multicolumn{4}{|l|}{ H. platirhinos } \\
\hline Saratoga Springs, Saratoga County, NY & $>250$ & 5 & $1^{\mathrm{a}}$ \\
\hline Greenfield Center, Saratoga County, NY & $>250$ & 8 & 3 \\
\hline Albany, Albany County, NY & $100->250$ & 6 & - \\
\hline Town of Oyster Bay, Nassau County, NY & $75->250$ & 5 & - \\
\hline Sterling Forest, Orange County, NY & $>100$ & 1 & - \\
\hline Luzerne, Warren County, NY & $>100$ & 1 & - \\
\hline Wilton, Saratoga County, NY & $>100$ & 1 & - \\
\hline no specific locality, Frederick County, VA & $>100$ & 1 & 1 \\
\hline Lake Whitney, Bosque County, TX & 5 & 1 & 1 \\
\hline \multicolumn{4}{|l|}{ H. nasicus } \\
\hline no locality data (captive bred) & 5 & 1 & 1 \\
\hline
\end{tabular}

Abbreviations: MAMU, mass-adjusted mouse unit; TTX, tetrodotoxin.

Locality information of Eastern Hog-nosed Snakes (H. platirhinos) and Plains Hog-nosed Snakes (H. nasicus) sampled for phenotypic (TTX resistance) and genotypic (SCN4A) variation, along with corresponding sample sizes $(n)$.

asample also used to obtain full transcript (cDNA) of SCN4A.

pore and permit selectivity and permeability of $\mathrm{Na}^{+}$through the channel also bind strongly to TTX, which fits into the outer pore through a combination of chemical bonds and steric attraction, essentially docking in the outer pore and blocking $\mathrm{Na}^{+}$movement (reviewed in Fozzard and Lipkind, 2010). Thus, we focused on variation in the portions of the four domains (DI-DIV) of SCN4A that code for the P-loops that interact with TTX; changes at specific P-loop sites 

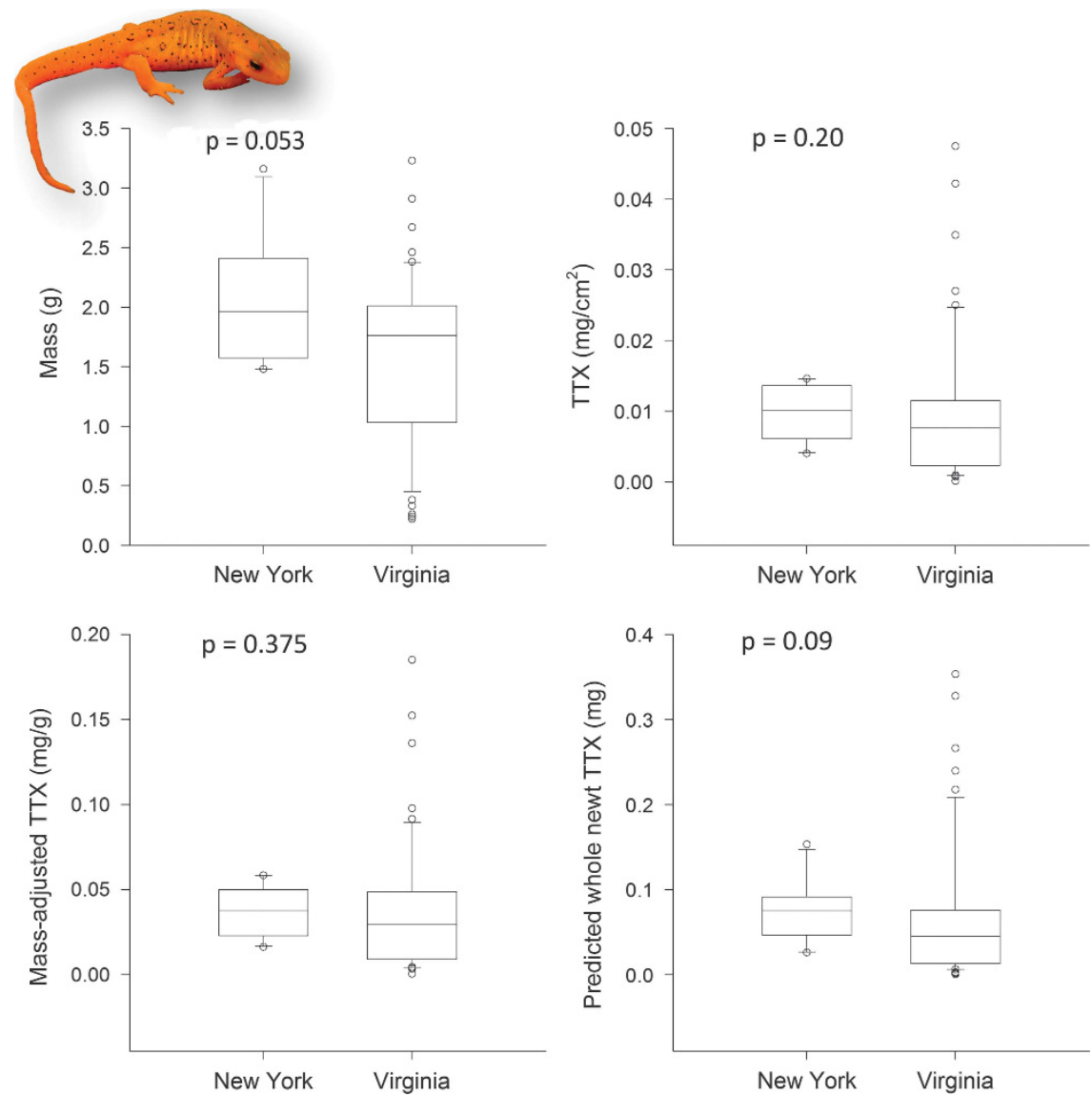

Figure 2 Box plots of body size and TTX levels in terrestrial stage (eft) Eastern Newts (N. viridescens) from Cortland County, NY ( $n=10)$, and Giles County, VA $(n=51)$. These two populations did not differ in comparisons of size or measures of TTX (see Results). Left top: newt body mass (g); Right top: concentration of TTX per skin sample ( $\mathrm{mg}$ of TTX per $\mathrm{cm}^{2}$ ). Left bottom: mass-adjusted concentration of TTX per individual (mg of TTX per gram of newt). Right bottom: estimated total amount of TTX per individual (mg). Inset shows the brightly colored eft stage of $N$. viridescens (photo by AMD).

are known to contribute to TTX resistance in vertebrates (for example, Geffeny et al., 2005; Soong and Venkatesh, 2006; Jost et al., 2008; Hanifin and Gilly, 2015).

We isolated and purified genomic DNA from muscle or liver tissue with the DNeasy Tissue Kit (Qiagen, Inc., Germantown, MD, USA). We amplified and sequenced the four P-loops of SCN4A using primers we designed specifically for snakes (Feldman et al., 2009).

We also attempted to sequence the entire coding region (coding DNA sequence) of a resistant $H$. platirhinos to potentially identify other novel genetic changes (for example, splice variation) that might provide TTX resistance. We isolated and purified mRNA from fresh skeletal muscle with the RNeasy Mini Plus Kit (Qiagen, Inc.). We reverse transcribed total mRNA to cDNA with the iScript Select cDNA Synthesis Kit (BioRad, Hercules, CA, USA) and oligo(dT) primer. We then amplified and sequenced a series of overlapping pieces of $S C N 4 A$ to construct a complete contig of the locus using primers we designed for snakes SCN4A (Feldman et al., 2009). We edited sequences by eye in Sequencher 4.9 (Gene Codes Corp., Ann Arbor, MI, USA), aligned sequences with Clustal W 1.83 (Thompson et al., 1994) and translated coding regions into amino acid sequences using MacClade 4.08 (Maddison and Maddison, 2005). We deposited all sequences in GenBank (accession numbers: KT277675KT277703).

\section{RESULTS}

Newt and snake phenotypes

Eastern Newts collected from central New York, just outside the distribution of Eastern Hog-nosed Snakes, contained a median concentration of $0.0374 \mathrm{mg}$ of TTX per gram of newt, which can be converted to a total quantity of $0.075 \mathrm{mg}$ of TTX in an eft (mean $=0.075 \mathrm{mg}, \max =0.153 \mathrm{mg}$ ). Newts from Virginia, where Eastern Hog-nosed Snakes occur, contained a median concentration of $0.0294 \mathrm{mg}$ of TTX per gram, for total estimate of $0.045 \mathrm{mg}$ of TTX in an eft (mean $=0.067 \mathrm{mg}, \max =0.353 \mathrm{mg})$. Although the population of newts sympatric with Heterodon displayed a greater range of toxicity, levels of TTX between the two sites were not statistically different $(t$-value $=356000, D F=39, P=0.375$; Figure 2).

All $H$. platirhinos sympatric with $N$. viridescens that we examined possessed highly elevated levels of TTX resistance (Table 2). Resistance in these populations ranged from 75 MAMUs to well over 250 MAMUs, with some snakes crawling at over $90 \%$ of their baseline speed even after injections of 250 MAMUs; doses of TTX that would kill almost any other terrestrial vertebrate (Hanifin, 2010). In contrast, the allopatric $H$. platirhinos and $H$. nasicus showed only base levels of resistance, on par with other nonresistant snakes (Table 2) (Feldman et al., 2012).

\section{Snake SCN4A genotypes}

To our surprise, all Heterodon possessed the same TTX-sensitive SCN4A allele ('wild type') seen in all nonresistant snakes (Figure 3) (Geffeny et al., 2005; Feldman et al., 2010, 2012; McGlothlin et al., 2014). 

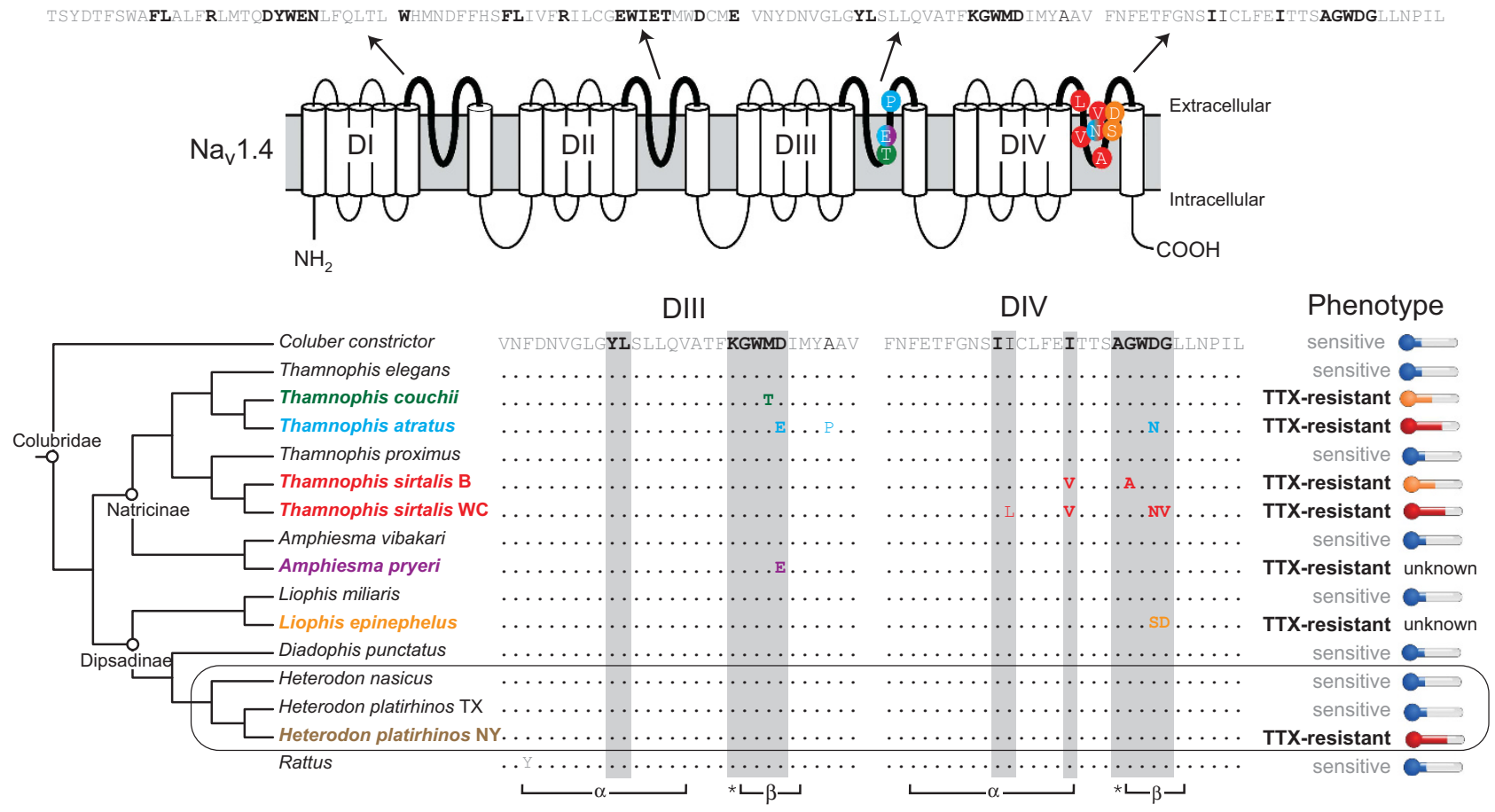

Figure 3 Amino acid replacements are found at sites critical in TTX ligation in the pore-forming loops (P-loops) of $\mathrm{Na}_{\mathrm{v}} 1.4$ in all snakes known to prey on TTX-bearing amphibians, except for Eastern Hog-nosed Snakes (H. platirhinos). Top: amino acid sequence of the 4P-loops (DI-DIV) of Na 1.4 ; sites in dark black have been demonstrated to reduce TTX-binding affinity at least twofold (see Feldman et al., 2012). Middle: two-dimensional model of Nav1.4 showing the placement of resistance-conferring substitutions in snakes. Bottom: genotypes and phenotypes of resistant snakes and close relatives (and Rattus) arranged phylogenetically (after Pyron et al., 2013). Taxa that prey on TTX-bearing amphibians (bold colors) also possess mutations (colors) at sites known to alter TTX ligation to the pore (bold, outlined in grey), with the exception of $H$. platirhinos. Pore features indicated below sequence: $\alpha$-helix $(\alpha)$; $\beta$-strand $(\beta)$; selectivity filter $\left(^{*}\right)$. Phenotypic data are categorized as follows: blue thermometers indicate TTX-sensitive animals (1-5 MAMUs), orange thermometers indicate moderate to high levels of TTX resistance (40-80 MAMUs), whereas red thermometers indicate extreme levels of TTX resistance (100->250 MAMUs). It is noteworthy that most $\mathrm{H}$. platirhinos display extreme levels of TTX resistance (Table 2), similar to the levels seen in Thamnophis that possess functionally important replacements in $\mathrm{Na}_{\mathrm{v}} 1.4$. Phenotypic data are from this study, Brodie et al. (2002, 2005), Feldman et al. (2009, 2012); two snake species (A. pryeri and L. epinephalus) are known to be resistant to their TTX-bearing prey and possess convergent TTX-resistant substitutions (Feldman et al., 2012), but actual levels of whole-animal TTX resistance have yet to be quantified (unknown).

No $H$. platirhinos possessed derived SCN4A alleles found in the other TTX-resistant taxa or paralogs that have been examined thus far (Figure 3) (Geffeny et al., 2005; Soong and Venkatesh, 2006; Jost et al., 2008; Feldman et al., 2012; McGlothlin et al., 2014; Hanifin and Gilly, 2015). Thus, the resistance-conferring mutations in SCN4A known to reduce the binding affinity of TTX to the channel appear to be entirely lacking in TTX-resistant $H$. platirhinos.

We also obtained a nearly complete transcript of the SCN4A locus from a highly resistant Eastern Hog-nosed Snake (we were unable to obtain the first $\sim 640$ bp and $\sim 430$ bp encoding most of exon 9 and all of exon 10, respectively). The coding DNA sequence from this snake appears consistent with that of other snakes (and mammals), as does gene structure (intron/exon arrangement), providing no indication that other changes to the protein or exon shuffling explain resistance in $H$. platirhinos. Furthermore, changes in the regions we were unable to sequence are not likely to contribute to resistance, because they do not interact with TTX (Fozzard and Lipkind, 2010). Specifically, the $\mathrm{N}$-terminus of $\mathrm{Na}_{\mathrm{v}} 1.4$ we could not sequence is not part of the outer pore, and although the missing portion of exons 9 and 10 are just C-terminal to the DI P-loop, these regions actually encode a portion of the inner pore, which is an inner membrane and cytoplasmic structure (thus unexposed to TTX) involved in channel inactivation (Catterall, 2000; Hille, 2001).

\section{DISCUSSION}

Across much of the eastern United States, it is now apparent that Eastern Hog-nosed Snakes (H. platirhinos) prey on Eastern Newts (N. viridescens) (Table 1; Figure 1) and may be engaged in an arms race mediated by TTX, similar to the well-characterized garter snake (Thamnophis) and Pacific newt (Taricha) system (Brodie and Brodie, 1999). Eastern Newts in sympatry and allopatry with Eastern Hognosed Snakes possess similar levels of TTX (Figure 2). Although the most toxic newt contained only $0.353 \mathrm{mg}$ TTX, roughly 80 times less than the most potent Taricha (Stokes et al., 2015), the amount of toxin present in Eastern Newts is still sufficient to provide protection against almost any predator (Brodie and Brodie, 1990). However, Eastern Hog-nosed Snakes, one of only a few vertebrates known to consume the terrestrial efts (summarized in Table 1), show remarkable levels of toxin resistance (Table 2), on par with the most resistant populations of Thamnophis (Brodie et al., 2002; Feldman et al., 2009, 2010) (Figure 3). In fact, all but the smallest $H$. platirhinos in these populations could safely consume the most toxic $N$. viridescens known 


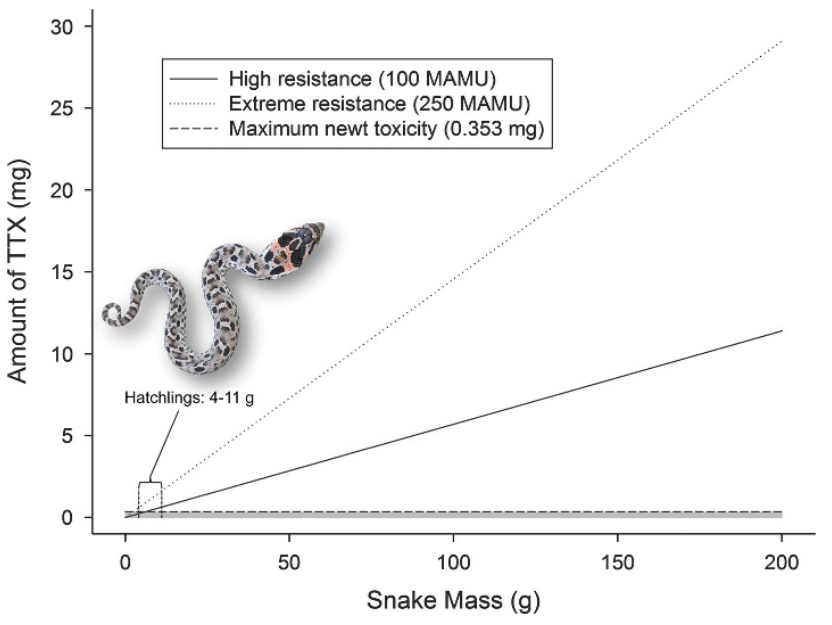

Figure 4 Projected levels of TTX required to slow $H$. platirhinos (NY samples) with high resistance (100 MAMUs; solid line) and extreme levels of resistance (250 MAMUs; dotted line) to $50 \%$ of their normal crawling ability, relative to the maximum amount of total TTX $(0.353 \mathrm{mg})$ in an individual $N$. viridescens (horizontal dashed line). Inset shows that $H$. platirhinos range in size from 4 to $11 \mathrm{~g}$ on hatching (Ernst and Ernst, 2003) and the curve for 100-MAMU snakes intersects the maximum newt toxicity threshold at $6.2 \mathrm{~g}$, whereas that of 250-MAMU snakes intersects at $2.4 \mathrm{~g}$, meaning that all but the smallest $H$. platirhinos from these populations could safely consume the most toxic $N$. viridescens known and would suffer $<50 \%$ reduction in crawling speed. It is worth noting that as the effects of TTX are mass dependent, projections can be made for any level of resistance and are useful in estimating the amount of TTX needed to slow a snake of a specific size compared with the amount of TTX in newt prey (after Brodie et al., 2005) (photo by AMD).

(this study) and suffer only mild reductions in crawling ability (Figure 4). Whether or not predator and prey traits are well matched across the distribution of both Eastern Hog-nosed Snakes and Eastern Newts remains an open question. Although our TTX-resistant Eastern Hog-nosed Snakes were sampled from within Eastern Newt range and our nonresistant $H$. platirhinos was from a locale outside newt range, we were unable to sample predator and prey from syntopic locations. Thus, there may be regions where Eastern Hog-nosed Snakes are less resistant to TTX and syntopic efts are more toxic than the populations we sampled, such that predator and prey can impose reciprocal selection on one another (for example, Hanifin et al., 2008). Much more extensive sampling across the distribution of these two interacting species is needed to sketch a picture of the geographic mosaic of coevolution in this system. Regardless of any geographic variation predator and prey traits, it is clear that some $H$. platirhinos populations have evolved phenotypic resistance in a parallel manner to the Thamnophis-Taricha system, but through a novel mechanism.

We then examined the genetic basis of the predator adaptation to determine whether a common genetic mechanism underlies TTX-resistant phenotypes in these disparate newt-snake systems (Heterodon and Thamnophis are members of distinct subfamilies and only distantly related; Figure 3 ). To date, the evolution of TTX resistance in all animal lineages examined appears to involve a predictable subset of replacements in the outer pore of the sodium channel proteins $\left(\mathrm{Na}_{\mathrm{v}}\right)$ that interact directly and strongly with TTX (Hille, 2001; Fozzard and Lipkind, 2010). Remarkably, in H. platirhinos, the SCN4A gene (encoding $\mathrm{Na}_{\mathrm{v}} 1.4$ ), a locus that appears to underlie a major portion of resistance in other vertebrates (Geffeny et al., 2005; Soong and Venkatesh, 2006; Jost et al., 2008; Feldman et al., 2012; Hanifin and Gilly, 2015), contains no allelic variation that would alter TTX ligation to the pore. Thamnophis with comparable levels of TTX resistance typically have two to four amino acid substitutions in this protein (Feldman et al., 2009, 2010) (Figure 3). Thus, Heterodon appears to have evolved a novel mechanism of TTX resistance.

Multiple, non-mutually exclusive hypotheses might explain resistance to TTX in Heterodon in the absence of allelic variation in $S C N 4 A$. The first involves simple posttranscriptional changes to the locus, such as RNA editing or alternative splicing (Liu et al., 2004; Onkal et al., 2008). However, our sequence of a nearly complete transcript reveals no such modifications. The second possibility involves changes in the expression patterns of sodium channels (for example, Lopez-Santiago et al., 2006). Simple upregulation of SCN4A might produce more copies of $\mathrm{Na}_{\mathrm{v}} 1.4$ than can be blocked by TTX. However, this mechanism seems unlikely, because major changes in sodium channel densities negatively impact electrophysiology and even impair normal cell and organ function (Chen et al., 2002). However, of the nine functional sodium channel paralogs in amniotes $\left(\mathrm{Na}_{\mathrm{v}} 1.1-1.9\right)$, each of which is expressed in a particular tissue type (Goldin, 2001), three are natively resistant to TTX $\left(\mathrm{Na}_{\mathrm{v}} 1.5\right.$ in cardiac muscle; $\mathrm{Na}_{\mathrm{v}} 1.8$ and 1.9 in peripheral nerves), owing to a major amino acid replacement in the outer pore (Backx et al., 1992). It is possible that one of these insensitive channels is expressed in the muscle tissue of $H$. platirhinos, thereby rendering the muscles impervious to TTX. An alteration in tissue-specific expression of this nature would likely compromise muscle performance to some degree, because the natively expressed $\mathrm{Na}_{\mathrm{v}} 1.4$ allows rapid, large amplitude changes in membrane potential compared with other channels (Geffeney and Rubin, 2006), allowing quick and intense muscular contractions. However, hog-nosed snakes are stout-bodied predators that rely on defensive displays rather than speed to avoid enemies (Durso and Mullin, 2014) and thus might tolerate some compromise in muscle function. Finally, an intriguing possibility is that H. platirhinos circumvent TTX not by possessing resistant sodium channels (targets of TTX) but by 'grabbing' TTX before the poison reaches sensitive tissues. In marine systems, some arthropods, gastropods and even pufferfish, possess TTX-binding proteins in specific tissues and blood (Matsui et al., 2000; Nagashima et al., 2002; Hwang et al., 2007). These proteins essentially wrap TTX and prevent it from binding to sodium channels, thereby disabling the toxin. Although TTX-binding proteins are unknown from snakes (or any other tetrapods), analogous proteins are employed by some snakes to defeat the effects of prey toxins or provide innate immunity to their own venoms (Weinstein et al., 1992; Mackessy, 2009). The fact that North American hog-nosed snakes are major predators of toxic toads (Ernst and Ernst, 2003) and these hog-nosed snakes are themselves venomous (Young, 1992) lends some credence to the hypothesis that binding agents already in place for dealing with prey toxins or selfimmunity may have been co-opted for TTX resistance.

Determining whether the genetic pathways to adaptation are predictable or unpredictable remains a central question in evolutionary biology (Stern and Orgogozo, 2009; Martin and Orgogozo, 2013) and one with real ramifications for human health, agriculture and other practical applications. Here, even in chemically mediated systems thought to be characterized by a high-degree of predictability, it is apparent that phenotypic convergence may still result from diverse genetic mechanisms. This example stands out as a reminder that even when common pathways and mechanisms exist, evolution may not be as constrained as we often assume. 


\section{DATA ARCHIVING}

All sequence data are available from GenBank (accession numbers: KT277675-KT277703).

\section{CONFLICT OF INTEREST}

The authors declare no conflict of interest.

\section{ACKNOWLEDGEMENTS}

We thank A Mortensen, J Scoville and A Wilkinson for captive care; K Kruse and C Osborne (UNR NGC) for lab assistance; and M Matocq, S Hegg, J Keehn, P Murphy, A de Queiroz, W Wüster and three anonymous reviewers for comments. We are grateful for help with field collections from J Jaycox and the NY Department of Environmental Conservation for permits (scientific permit 1487), especially A Breisch. We thank USU IACUC (1008) for approval of protocols and funding from NSF (DEB 0922216 to EDB III, DEB 1034686 to MEP and IOS 1355221 to CRF).

Backx PH, Yue DT, Lawrence JH, Marban E, Tomaselli GF (1992). Molecular localization of an ion-binding site within the pore of mammalian sodium channels. Science 257: 248-251.

Barnett K, Breisch A, Bruchac J, Abbuhl B (2006). Heterodon platirhinos (Eastern Hognose Snake): regurgitation of prey. Herpetol Rev 37: 352.

Brakefield PM (2006). Evo-devo and constraints on selection. Trends Ecol Evol 21 362-368.

Brodie ED Jr (1968a). Investigations on the skin toxin of the adult rough-skinned newt, Taricha granulosa. Copeia 2: 307-313.

Brodie ED Jr (1968b). Investigations on the skin toxin of the red-spotted newt, Notophthalmus viridescens viridescens. Am Midl Nat 80: 276-280.

Brodie ED III, Brodie ED Jr (1990). Tetrodotoxin resistance in garter snakes: An evolutionary response of predators to dangerous prey. Evolution 44: 651-659.

Brodie ED III, Brodie ED Jr. (1999). Predator-prey arms races: asymmetrical selection on predators and prey may be reduced when prey are dangerous. Bioscience 49: 557-568.

Brodie ED III, Feldman CR, Hanifin CT, Motychak JE, Mulcahy DG, Williams BL et al. (2005). Parallel arms races between garter snakes and newts involving tetrodotoxin as the phenotypic interface of coevolution. J Chem Ecol 31: 343-356.

Brodie Jr ED, Hensel Jr JL, Johnson JA (1974). Toxicity of the urodele amphibians Taricha, Notophthalmus, Cynops, and Paramesotriton (Salamandridae). Copeia 1974: 506-511.

Brodie ED III, Ridenhour BJ (2003). Reciprocal selection at the phenotypic interface of coevolution. Int Comp Bio/ 43: 408-418.

Brodie Jr ED, Ridenhour BJ, Brodie ED III (2002). The evolutionary response of predators to dangerous prey: hotspots and coldspots in the geographic mosaic of coevolution between garter snakes and newts. Evolution 56: 2067-2082.

Catterall WA (2000). From ionic currents to molecular mechanisms: the structure and function of voltage-gated sodium channels. Neuron 26: 13-25.

Chen CL, Bharucha V, Chen YA, Westenbroek RE, Brown A, Malhotra JD et al. (2002). Reduced sodium channel density, altered voltage dependence of inactivation, and increased susceptibility to seizures in mice lacking sodium channel $\beta 2$-subunits. Proc Natl Acad Sci USA 99: 17072-17077.

Christin P-A, Weinreich DM, Besnard G (2010). Causes and evolutionary significance of genetic convergence. Trends Genet 26: 400-405.

Conte GL, Arnegard ME, Peichel CL, Schluter D (2012). The probability of genetic parallelism and convergence in natural populations. Proc $R$ Soc Lond B Biol Sci 279 5039-5047.

Durso AM, Mullin SJ (2014). Intrinsic and extrinsic factors influence the expression of defensive behaviors in plains hog-nosed snakes (Colubridae: Heterodon). Ethology 120: 140-148.

Ernst CH, Ernst EM (2003). Snakes of the United States and Canada. Smithsonian: Washington, DC

Feldman CR, Brodie Jr ED, Brodie ED III, Pfrender ME (2009). The evolutionary origins of beneficial alleles during the repeated adaptation of garter snakes to deadly prey. Proc Natl Acad Sci USA 106: 13415-13420.

Feldman CR, Brodie Jr ED, Brodie ED III, Pfrender ME (2010). Genetic architecture of a feeding adaptation: garter snake (Thamnophis) resistance to tetrodotoxin bearing prey. Proc R Soc Lond B Biol Sci 277: 3317-3325.

Feldman CR, Brodie Jr ED, Brodie ED III, Pfrender ME (2012). Constraint shapes convergence in tetrodotoxin-resistant sodium channels of snakes. Proc Natl Acad Sci USA 109: 4556-4561.

Fozzard HA, Lipkind GM (2010). The tetrodotoxin binding site is within the outer vestibule of the sodium channel. Marine Drugs 8: 219-234.

Futuyma DJ (2013). Evolution, 3rd edn. Sinauer Associates, Inc.: Sunderland, MA, USA.

Geffeney SL, Fujimoto E, Brodie ED III, Brodie ED Jr, Ruben PC (2005). Evolutionary diversification of TTX-resistant sodium channels in a predator-prey interaction. Nature 434: 759-763.
Geffeney SL, Rubin PC (2006). The structural basis and functional consequences of interactions between tetrodotoxin and voltage-gated sodium channels. Mar Drug 4 $143-156$.

Goldin AL (2001). Resurgence of sodium channel research. Annu Rev Physiol 63: 871-894.

Gompel N, Prud'homme B (2009). The causes of repeated genetic evolution. Dev Bio/ 332 36-47.

Hanifin CT (2010). The chemical and evolutionary ecology of tetrodotoxin (TTX) toxicity in terrestrial vertebrates. Mar Drug 8: 577-593.

Hanifin CT, Brodie ED III, Brodie ED Jr (2002). Tetrodotoxin levels of the rough-skin newt, Taricha granulosa, increase in long-term captivity. Toxicon 40: 1149-1153.

Hanifin CT, Brodie ED III, Brodie ED Jr (2004). A predictive model to estimate total skin tetrodotoxin in the newt Taricha granulosa. Toxicon 43: 243-249.

Hanifin CT, Brodie ED Jr, Brodie ED III (2008). Phenotypic mismatches reveal escape from arms-race coevolution. Pub Libr Sci Biol 6: e60.

Hanifin CT, Gilly WF (2015). Evolutionary history of a complex adaptation: tetrodotoxin resistance in salamanders. Evolution 69: 232-244.

Hille B (2001). Ion Channels of Excitable Membranes, 3rd edn. Sinauer Associates: Sunderland, MA.

Hurst G (1963). A phenological study of the herpetofauna of William B. Umstead and Reedy Creek State Parks, Wake County, North Carolina. MS thesis, North Carolina State University: Raleigh, NC.

Hwang PA, Tsai YH, Lin HP, Hwang DF (2007). Tetrodotoxin-binding proteins isolated from five species of toxic gastropods. Food Chem 103: 1153-1158.

Jost MC, Hillis DM, Lu Y, Kyle JW, Fozzard HA, Zakon HH (2008). Toxin-resistant sodium channels: parallel adaptive evolution across a complete gene family. Mol Biol Evol 25 1016-1024.

Koch C (2009). The year of the hognose. Bull Chicago Herpetol Soc 44: 17-20.

Lehman E (2007). Techniques: a simplified and inexpensive method for extraction and quantification of tetrodotoxin from tissue samples. Herpetol Rev 38: 298-300.

Liu Z, Song W, Dong K (2004). Persistent tetrodotoxin-sensitive sodium current resulting from U-to-C RNA editing of an insect sodium channel. Proc Natl Acad Sci USA 101: $11862-11867$.

Lopez-Santiago LF, Pertin M, Morisod X, Chen CL, Hong SS, Wiley J et al. (2006). Sodium channel $\beta 2$ subunits regulate tetrodotoxin-sensitive sodium channels in small dorsal root ganglion neurons and modulate the response to pain. J Neurosci 26 7984-7994.

Losos JB (2011). Convergence, adaptation, and constraint. Evolution 65: 1827-1840.

Mackessy SP(ed) (2009). Handbook of Venoms and Toxins of Reptiles. CRC Press: Boca Raton, FL.

Maddison DR, Maddison WP (2005). MacClade: analysis of phylogeny and character evolution.

Martin A, Orgogozo V (2013). The loci of repeated evolution: a catalog of genetic hotspots of phenotypic variation. Evolution 67: 1235-1250.

Matsui T, Yamamori K, Furukawa K, Kono M (2000). Purifcation and some properties of a tetrodotoxin binding protein from the blood plasma of kusafugu, Takifugu niphobles. Toxicon 38: 463-468.

Maynard Smith J, Burian R, Kauffman S, Alberch P, Campbell J, Goodwin B et al. (1985). Developmental constraints and evolution. Q Rev Biol 60: 265-287.

McDonald J (1987). Dramas at the forest pool. Penn Angler 56: 15-19.

McGhee GR (2011). Convergent Evolution: Limited Forms Most Beautiful. MIT Press: Cambridge, MA.

McGlothlin JW, Chuckalovcak JP, Janes DE, Edwards SV, Feldman CR, Brodie ED Jr et al (2014). Parallel evolution of tetrodotoxin resistance in three voltage-gated sodium channel genes in the garter snake Thamnophis sirtalis. Mol Biol Evol 31: 2836-2846.

Miller SP, Lunzer M, Dean AM (2006). Direct demonstration of an adaptive constraint. Science 314: 459-461.

Moczydlowski EG (2013). The molecular mystique of tetrodotoxin. Toxicon 63: $165-183$.

Nagashima Y, Yamamoto K, Shimakura K, Shiomi K (2002). A tetrodotoxin-binding protein in the hemolymph of shore crab Hemigrapsus sanguineus: purification an properties. Toxicon 40: 753-760.

Onkal R, Mattis JH, Fraser SP, Diss JKJ, Shao D, Okuse K et al. (2008). Alternative splicing of Nav1.5: an electrophysiological comparison of 'neonatal' and 'adult' isoforms and critical involvement of a lysine residue. J Cell Physiol 216: 716-726.

Palmer WM, Braswell A (1995). Reptiles of North Carolina. University of North Carolina Press: Chapel Hill, NC.

Pyron RA, Burbrink FT, Wiens JJ (2013). A phylogeny and revised classification of Squamata, including 4161 species of lizards and snakes. BMC Evol Biol 13: 93.

Ridenhour BJ, Brodie ED III, Brodie ED Jr (2004). Resistance of neonates and field-collected garter snakes (Thamnophis spp.) to tetrodotoxin. J Chem Ecol 30: $143-154$

Schluter D (2000). The Ecology of Adaptive Radiation. Oxford University Press: Oxford.

Soong TW, Venkatesh B (2006). Adaptive evolution of tetrodotoxin resistance in animals. Trends Genet 22: 621-626.

Stern DL, Orgogozo V (2009). Is genetic evolution predictable? Science 323: 746-751.

Stokes AN, Ray AM, Buktenica MW, Gall BG, Paulson E, Paulson D et al. (2015). Tetrodotoxin levels in high elevation populations of Taricha granulosa in Oregon and predation by otters. Northwest Nat 96: 13-21.

Stokes AN, Williams BL, French SS (2012). An improved competitive inhibition enzymatic immunoassay method for tetrodotoxin quantification. Biol Proced Online 14: 3 . 
Thompson JD, Higgins DG, Gibson TJ (1994). CLUSTAL W: improving the sensitivity of progressive multiple sequence alignment through sequence weighting, positive-specific gap penalties and weight matrix choice. Nucleic Acids Res 22 4673-4680.

Uhler F, Cottam C, Clarke T (1939). Food of snakes of the George Washington National Forest, Virginia. Trans North Amer Wildlife Congr 4: 605-622.

Wake DB (1991). Homoplasy: the result of natural selection, or evidence of design limitations? Am Naturalist 138: 543-567.

Weinreich DM, Delaney NF, DePristo MA, Hartl DL (2006). Darwinian evolution can follow only very few mutational paths to fitter proteins. Science 312: 111-114.
Weinstein SA, Dewitt CF, Smith LA (1992). Variability of venom-neutralizing properties of serum from snakes of the colubrid genus Lampropeltis. J Herpetol 26: 452-461.

Williams C (2011). Eastern Hog-nosed Snake (Heterodon platirhinos). Record number 65849 in Herpetol Edu Res Proj, 2013 <http://www.naherp.com/viewrecord.php? r_id=65849>

Yasumoto T, Michishita T (1985). Fluorometric-determination of tetrodotoxin by highperformance liquid-chromatography. Agric Biol Chem 49: 3077-3080.

Young RA (1992). Effects of duvernoy's gland secretions from the eastern hognose snake, Heterodon platirhinos, on smooth muscle and neuromuscular junction. Toxicon 30: 775-779. 